\title{
$\mathrm{S}$ 字形状ディフューザ管路内乱流の応力場解析*
}

\author{
杉山均*1, 秋山光 庸*1, 村上泰 隆*2

\section{Numerical Analysis of Reynolds Stresses for Turbulent Flow Developing in S-Shaped Diffuser}

\author{
Hitoshi SUGIYAMA, Mitsunobu AKIYAMA and Yasutaka MURAKAMI
}

\begin{abstract}
A numerical analysis has been carried out for developing turbulent flow in a diffuser with $\mathrm{S}^{-}$ shaped centerline at a Reynolds number of $4 \times 10^{4}$. The diffuser exit to-inlet area ratio was 1.5 and the inler cross section was square, $40 \mathrm{~mm} \times 40 \mathrm{~mm}$, and expanded on both curved surfaces to an enitplane section of $40 \mathrm{~mm} \times 60 \mathrm{~mm}$. The S-shaped curvature was formed from two 22.5 degree bends of $280 \mathrm{~mm}$ mean radius of curvature. Straight ducts $0.3 \mathrm{~m}$ and $2 \mathrm{~m}$ long are attached to the inlet and outlet planes of the $\mathrm{S}$-shaped diffuser, respectively. In the calculation, an algebraic Reynolds stress model was adopted in order to predict anisotropic turbulence precisely, and a boundary-fitted coordinate system was introduced as the method of coordinate transformation. Special attention is paid to the comparison of Reynolds stresses between calculation results and experimental data. In addition, the difference in turbulent structure between S-shaped diffuser and S-shaped duct is presented by invariant analysis using the calculation results. The present method can be used accurate prediction of the characteristic features of normal and shear stresses. Invariant maps of the $\mathrm{S}$-shaped diffuser show that the turbulent structure transforms anisotropic turbulent flow into a two -dimensional turbulent flow. Moreover, the calculation results suggent that the turbulence level of the S-shaped diffuser increases more actively than does that of the S-shaped duct.
\end{abstract}

Key Words: Numerical Analysis, Turbulent Flow, S-Shaped Diffuser, Reynolds Stress Model, Boundary-Fitted Coordinate System

\section{1. 緒言}

曲がりを有しかつ流れ方向に断面積が増加する曲が りディフューザ管路は空気調和設備, 熱交換器あるい は航空機エンジンへの空気導入管路など圧力損失の低 減を図りながら流れ方向を変換する継手管路として多 くの分野にて活用されている。こうした管路が活用さ れる流れ場の多くは乱流であり，その流れは複雑であ る. 本解析では曲がりと断面形状変化より構成された S字形状ディフューザ内の乱流場を対象とする.

曲がり管路に関しては多くの研究(1)(2) が報告されて いるが, S字形状管路に関する報告は少ない，断面形 状変化を伴わないS字形状管路に関する研究とし, 古 くはBansod-Bradshaw ${ }^{(3)}$ の実験がある。彼らは円形 断面を有方る 3 種類のS 字形状管路を対象に乱流計 測を報告している，彼らは航空機用エンジンの空気流 入部としての効䜌向上を図る目的から二次流れ，静压: 分布，壁酒杽擦係数分布を測定した. TaylorWhitelaw-Yianneskis ${ }^{(4)}$ も 円形断面 S 字管路を対象 とした計測結果を報告している。彼らは層流，乱流

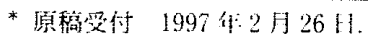

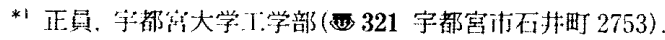

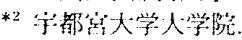

場をレーザドップラー流速計にて测定し, 乱流の場 合, 一次流れの最大は第 1 曲がり管路で生成され断面 平均速度 $12 \%$ に達することを報告している。また， Taylor-Whitelaw-Yianneskis ${ }^{(5)}$ は Taylor $ら^{(4)}$ の行 った S 字形状管路と同一形状で断面形状のみが正方 形断面と異なる管路を対象にレイノルズ応力分布を含 む詳細な乱流計測を平均速度場とともに示している。 Shimizu-Futaki-Marti ${ }^{(6)}$ は長方形断面を有し S 字形 状管路をいくつか組合せた波状管路を対象として時間 平圴速度, 二次流れ挙動をレーザドップラー流速計, タフト法より明らかにした。また須藤・高見・藤田 ${ }^{(7)}$ は曲率半径比 2 (水力直径に対する曲がり流路中心ま での半径比)で正方形断面を有し曲がり角 $180^{\circ}$ の管路 を 3 個組合せた繰返し曲がり管路内の乱流場を対象に 二次流れ分布, 主流方向速度分布, 乱流エネルギー分 布を熱線流速計を用い測定している。特に二次流れ， 主流方向速度分布に関して詳細な計測結果を報告して いる.

以上の断面形状変化のない $\mathrm{S}$ 字形状管路に対し, S 字形状ディフューザ管路に関する報告はさらに少な い. McMillan(8) は $40^{\circ}$ の単一曲がりを有し，入日に 対する出门断面積比 1.5 のディフューザを対象に熱線 流速計によりディフューザ各断面に扔ける二次流れ分 
布，乱流強度を測定している。こうした状況にあって Rojas-Whitelaw-Yianneskis ${ }^{(9)}$ は'Taylor-WhitelawYianneskis $^{(5)}$ のS 字形状管路を改造し, 流れ方向に 断面積が拡大するディフューザ管路を対象にレーザド ップラー流速計を用い平均速度場, 応力場の詳細な乱 流計測を報告している。さらに Rojas-WhitelawYianneskis ${ }^{(10)}$ は感温液晶膜を用いて単一 $45^{\circ}$ 曲がり ディフューザ管路, S 字形状ディフューザ管路内のヌ ッセルト数分布を測定している.

以上に示したように Taylor らはS 字形状管路に関 して系統的な実験結果を報告している．彼らは実験目 的の一つの乱流モデル検証のためのベンチマーク問題 とし計測結果を活用することを言及しているが，この 種のS 字管路に関する数值解析例も実験同椂少ない. そこで著者らは Taylor ら(5) のS 字形状管路を対象に 代数応力モデルを用い速度場(11), 応力場 ${ }^{(12)}$ の両結果 を比較することより解析手法, 代数応力モデルの妥当 性を示した。Lien-Leschziner ${ }^{(13)}$ は高レイノルズ数 型, 低レイノルズ数型および二層 $k-\varepsilon$ 二方程式乱流も デルを用いRojasら (9) のS 字形状ディフューザを解 析している。彼らの乱流モデルは等方的渦粘性モデル であるため各応力の比較は示されていない。そこで著 者ら ${ }^{(14)}$ も Rojas ら ${ }^{(9)}$ のS 字形状ディフューザ管路を 対象に代数応力モデルを用いて解析し, 特に平均速度 場を比較して実験を比較的良好に再現できることを示 した。

以上の研究経緯から, 本解析においては Rojas ら (9) のS 字形状ディフューザを対象にそのレイノルズ応 力場を比較検討することを目的とする.さらにディフ ューザ部をもたない $\mathrm{S}$ 字形状管路内の応力場とも比 較しこの種の管路における新たな知見を得ることを試 みる. 解析に際しては代数応力モデル, 複雑形状への 境界条件設定が容易な境界適合座標系を導入し三次元 乱流場として解析する。
$U_{r}:$ 円筒座標上の半径方向時間平均速度
$U_{z}$ : 円筒座標上の哚さ方向時間平均速度
$U_{\theta}:$ 円筒座標上の円周方向時間平均速度
$u_{i} u_{j}:$ レイノルズ応力
$u_{r}:$ 円筒座標上の半径方向変動速度
$u_{z}:$ 円筒座標上の深さ方向変動速度
$u_{\theta}:$ 月筒座標上の円周方向変動速度
$X_{i}$ : 直交座標系での $i$ 方向座標軸
$\theta:$ 曲がり角度
$\nu:$ 粘性係数
$\pi_{i j}:$ 圧力・ひずみ相関項
$\rho:$ 密度

\section{3. 解 析 手 法}

$3 \cdot 1$ 計算対象実駼 計算対象としたRojasWhitelaw-Yianneskis ${ }^{(9)}$ の実験装置概略図，ならびに 座標系を図 1 に示す。装置は一辺が $D=40 \mathrm{~mm}$, 長さ $300 \mathrm{~mm}$ の正方形断面を有する入口直管部, S 字形状 ディフューザ部, 長さ $2000 \mathrm{~mm}$ の出口直管部の 3 種 類の管路より構成されている。ディフューザ部は曲が り開始位置から始まり $45^{\circ}$ の曲がり角度を経て 40 $\mathrm{mm} \times 60 \mathrm{~mm}$ (繸 $\times$ 横)の長方形断面に変化する。 $\mathrm{S}$ 字 形状曲がり部は曲がり角度 $22.5^{\circ}$ の比較的滑らかな二 つの曲がり管路より構成されている，実験に際しては 作動流体に水を用い,レーザドップラー流速計にて時 間平均速度，ならびに乱流特性量の測定を行ってい る. 測定断面は図 1 中に示した断面(1)〜(5)であり断面 (1)は S 字ディフューザ入口, 断面(2)は S 字ディフュ ーザ入口から $13.5^{\circ}$ の位置, 断面(3は $20.5^{\circ}$ の位置, 断面(4) S 字ディフューザ出口から上流部に向かっ て $13.5^{\circ}$ の位置, 断面(5) S 字ディフューザ出口に相 当している.レイノルズ数は入口直管部での断面内平

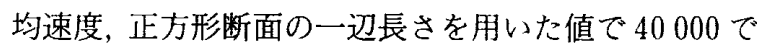
ある。このときのディーン数は $D e=10690$ である.

\section{2.おもな記号}

$D:$ 入口直管部の一辺長さ

$D e:$ ディーン数 $=\operatorname{Re} \sqrt{D_{h} / 2 R_{c}}$

$D_{h}:$ 水力直径

$r:$ 流路内の任意な位置までの半径

$r_{c}:$ 曲がり流路中心位置までの半径

$r_{i}:$ 内壁面までの曲率半径

$r_{o}:$ 外壁面までの曲率半径

$R e:$ レイルズ数 $=U_{b} D / \nu$

$U_{b}:$ 入口直管部での主流方向平均速度

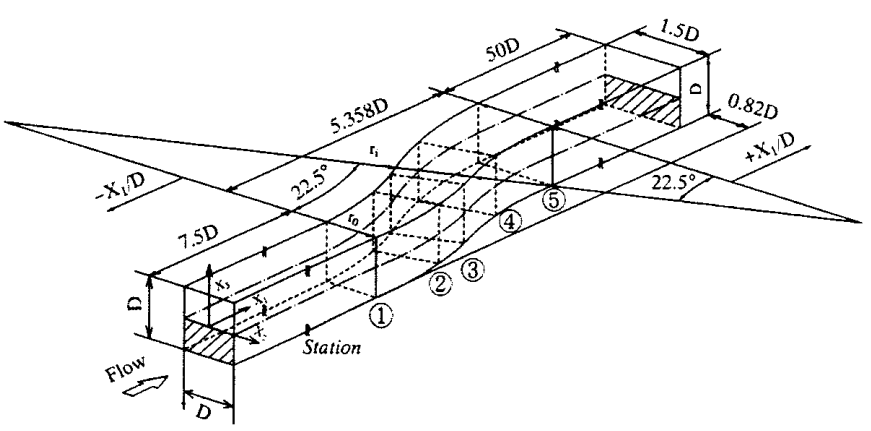

Fig. 1 S-shaped diffuser and definition of coordinate system 
座標系は主流方向を $X_{1}$ 軸，断面方向をそれぞれ $X_{2}, X_{3}$ 軸とし原点は正方形断面中心とした。曲がり 部においては便宜的に円筒座標系に従うものとした。 したがって $U_{v}, U_{r}, U_{z}$ は主流方问, 半径方向, 深さ 方向 ( $X_{3}$ 軸方向) の各速度成分を示している.

$3 \cdot 2$ レイノルズ応力輸送方程式 レイノルズ㐫 力輸送方程式の厳密式は次式のように示される。

$$
\begin{aligned}
& \frac{\overline{D u_{i} u_{j}}}{D t}=-\left(\overline{u_{i} u_{k}} \frac{\partial U_{j}}{\partial X_{k}}+\overline{u_{j} u_{k}} \frac{\partial U_{i}}{\partial X_{k}}\right) \\
& +\frac{\bar{p}\left(\frac{\partial u_{i}}{\partial X_{j}}+\frac{\partial u_{j}}{\partial X_{i}}\right)}{\rho}-\frac{\partial}{\partial X_{k}}\left\{\overline{u_{i} u_{j} u_{k}}-\nu \frac{\partial \overline{u_{i} u_{j}}}{\partial X_{k}}\right. \\
& +\frac{\bar{p}\left(\delta_{j k} u_{i}+\delta_{i k} u_{j}\right)}{\rho}-2 \nu \overline{\frac{\partial u_{i}}{\partial X_{k}} \frac{\partial u_{j}}{\partial X_{k}}} \cdots \cdots(1)
\end{aligned}
$$

数値計算の際障害となるのが左辺の対流項, ならびに 右辺第 3 項の拡散項である。従来のモデルでは，これ らの項を省略してモデル化を行っているが, 対流項, 拡散項の影響を考慮する意味より，Rodi ${ }^{(15)}$ 近似を適 用しモデル化を行った。 さらにモデル化のうえで特に 問題となる王力・ひずみ相関項のモデル化，ならびに その定数に関する詳細については別報 ${ }^{(16)} に て$ 詳述し た。

$3 \cdot 3$ 境界適合座標 境界適合座標系による計算 手法は, 物理平面上の解析領域を計算領域へと座標変 換し計算平面上で支配方程式を解く手法である。境界 条件の設定, 万程式の離散化が容易な反面, 変換され た支配方程式が複雑になるという特徴をもつ，支配方 程式の計算平面上への変換は次の数学定理より変換さ れる。

$$
\frac{\partial}{\partial X_{i}}=\frac{\partial \xi}{\partial X_{i}} \frac{\partial}{\partial \xi}+\frac{\partial \eta}{\partial X_{i}} \frac{\partial}{\partial \eta}+\frac{\partial \zeta}{\partial X_{i}} \frac{\partial}{\partial \zeta}
$$

上式中 $\xi, \eta, \zeta$ は変換された計算平面での座標軸を示 している，上式を用いた各方程式の変換法, 変換によ り導出される輸送方程式, 反変速度, 計量テンソルな どは別報において詳述した(17)。

3.4 数値解析 計算に際しては, 系の対称性を 考慮し図 1 の斜線で示す $1 / 2$ 断面にて解析を行った。 $\mathrm{S}$ 字形状ディフューザ入口，出口部には実験と同じ助 走区間を設けた。図 2 に計算格子を示す。図 2 中の $\zeta 、 \eta, \xi$ は計算平面上の座標系を示し格子に沿う座標 を示している，図 2 にはディフューザ入口，出口断面 の計算格子分布を同時に示した， $X_{3}$ 軸方向に $21 ， X_{2}$ 軸方向に 41, 流れ方向に 130 の計算格子を設けた。計 算時のレイノルズ数は実験も同じ 40000 である。本 解析では高レイノルズ数型の乱流モデルを用いている ため乱流エネルギー, 乱流散逸方程式の境界条件には

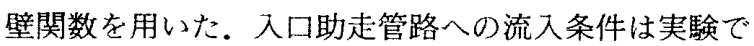
も不明なため乱流エネルギー, 乱流散逸做は $k=U_{b}^{2} \times$

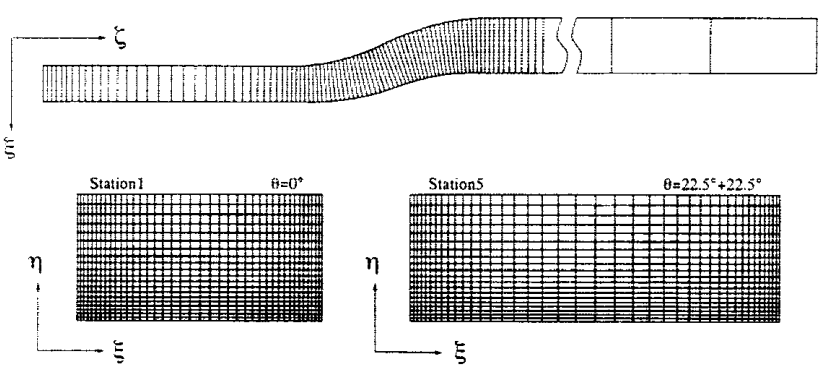

Fig. 2 Computational mesh

$10^{-5}, \varepsilon=k^{3 / 2} / D_{h}$ と小さな值を設定し解析を行った。 出口境界条件はノイマン条件とし, 式の離散化は有限 差分近似により行い, 各計算諸量の格子点配置は Regular Grid法によった. 支配方程式中の対流項差 分近似は QUICK (三次精度の風上差分)を，それ以外 の項に関しては中心差分を使用した。また，数值解析 に際しては支配方程式を三次元だ円形方程式として扱 い解析を行った。

\section{4. 結果と考察}

$4 \cdot 1$ 垂直応力場における比較 図 3 に S 字形状 ディフューザの主流方向垂值応力分布を比較した結果 を示す．各等值線は実験にならい入口直管部の主流方 向平均速度 $U_{b}$ にて無次元化した. 第 1 曲がり管路に あたる $\theta=0,13.5,20.5^{\circ}$ の計算結果から，曲がり入 口部の内外壁および底壁に認められる 1.00 等值線が 占める領域は曲がりが進むにつれて内壁近傍で大きな 領域を形成することがわかる．さらに第 2 の曲がり管 路に流入するとこの増加傾问は顕著となり，第 1 曲が り管路の内壁に相当する第 2 曲がり管路外壁側にさら に大きな乱れが生成されることになる，この傾向はデ イフューザ出口断面の $\theta=22.5^{\circ}+22.5^{\circ}$ でも認められ る.ディフューザの影響を知るためS 字形状管路に おける実験(5)，計算結果 ${ }^{(12)}$ を図 4 に示卞。図 4 にはS 字形状部の下流に相当する $22.5^{\circ}+9^{\circ}, 22.5^{\circ}+22.5^{\circ}$ の断面を示した，計算結果を比較するとディフューザ 管路のほうが外壁近傍にて大きな乱れを生成している ことがわかる。こうしたディフューザ外壁近傍にて大 きな値を有するのは以下のように説明される。曲がり 部における主流方向変動速度の生成項を $\operatorname{Pr}\left(\overline{u_{\theta}^{2}}\right)$ とす ると，その厳密式は以下のように示される。

$$
\begin{aligned}
& \operatorname{Pr}\left(\overline{u_{\theta}^{2}}\right)=-2 \overline{u_{\theta} u_{r}} \frac{\partial U_{\theta}}{\partial r}-2 u_{\theta}^{2}\left(\frac{1}{r} \frac{\partial U_{\theta}}{\partial \theta}+\frac{U_{r}}{r}\right) \\
& -2 \overline{u_{\theta} u_{z}}-\frac{\partial U_{\theta}}{\partial Z}
\end{aligned}
$$

$\mathrm{S}$ 字形状管路とディフューザ管路との大きな相違は 

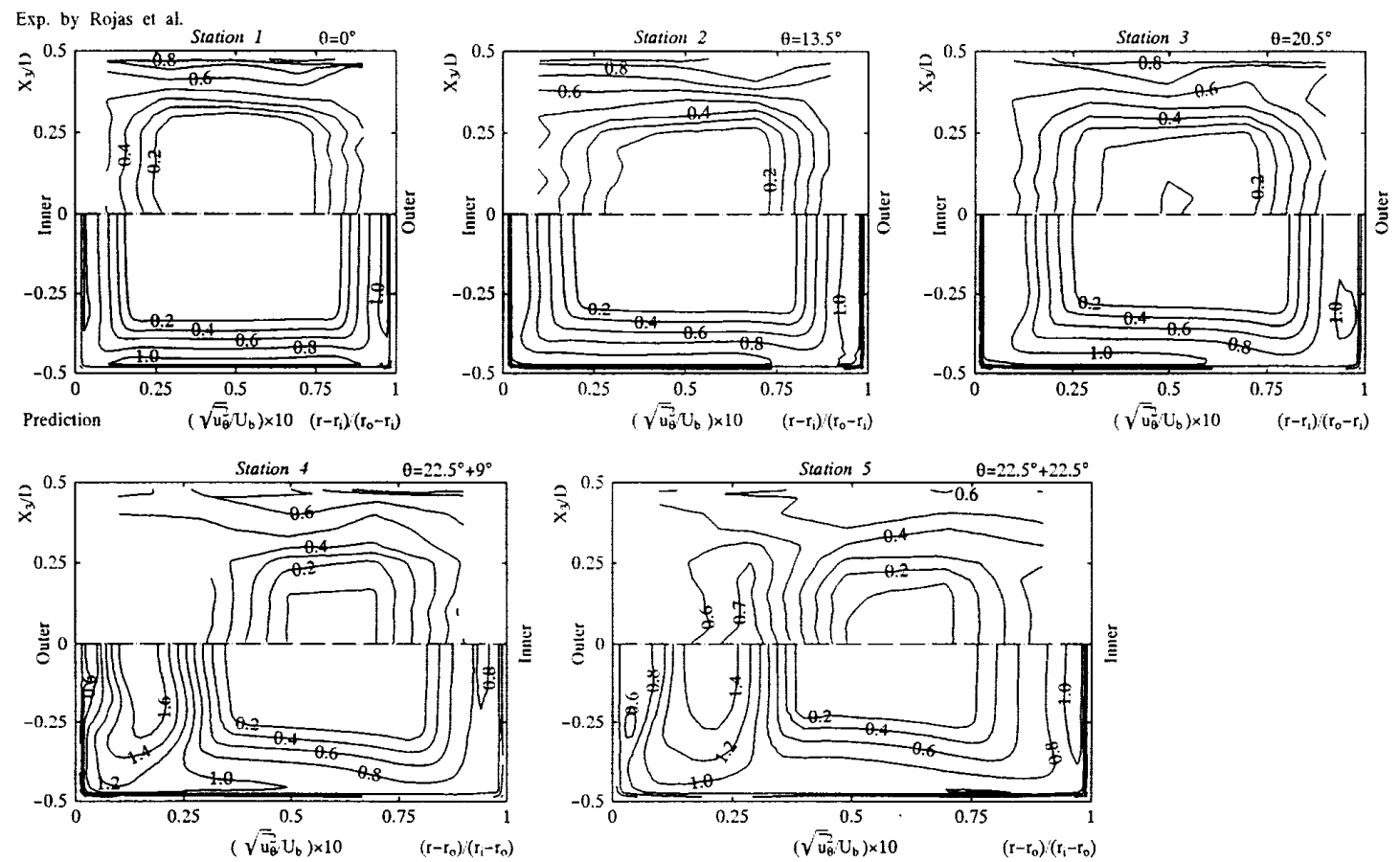

Fig. 3 Comparison of streamwise normal stress
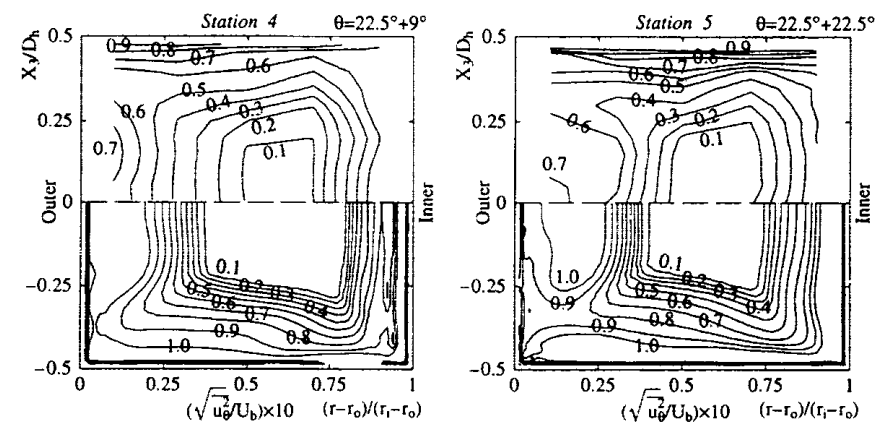

Fig. 4 Comparison of streamwise normal stress S-shaped duct

ディフューザ管路では大きな減速流を伴うことであ

り，上式中第 2 項めがその生成に大きく寄与する。第 2 項に含まれる $U_{\theta}$ の流れ方向の変化はディフューザ 管路ではつねに負であることより，第2 項はつねに正 值を有し主流方向垂直応力の生成を促進させる。この 減速割合は第 2 曲がり管外壁近傍にて顕著であり $\theta=$ $22.5^{\circ}+9^{\circ}, 22.5^{\circ}+22.5^{\circ}$ の外壁にて大きな值が生成 される、また，実験は内外壁の等值線が示されておら ず，この領域にて直接比較はできないが,この領域を 除いた領域で計算は実験を比較的良好に予測してい る.

図 5 は半径方向垂淔応力の等值線分布を比較した結 果である. $\theta=0^{\circ}$ では両結果とも上下壁面に比較的高 い值が存在する。半径方向垂值心力は内外壁によりそ の生成が抑制されるため，上下壁面近傍にて最大值を 有することになる。さら下流の $\theta=13.5,20.5^{\circ}$ に
至ると計算結果は底壁面ばかりでなく内壁近傍におい ても比較的高い值を有する領域が形成されることを示 している．計算結果よりこの傾向は第 2 曲がり管路に 流入するとさらに顕著に認められる。こうした現象は その生成項ならびに圧力・ひずみ相関項が大きく寄与 するものと解釈される。半径方向変動速度の生成項を $\operatorname{Pr}\left(u_{r}^{2}\right)$ とすると, 次式のように示される.

$$
\begin{gathered}
\operatorname{Pr}\left(\overline{u_{r}^{2}}\right)=-2 \overline{u_{r}^{2}} \frac{\partial U_{r}}{\partial r}-2 \overline{u_{\theta} u_{r}}\left(\frac{1}{r} \frac{\partial U_{r}}{\partial \theta}-\frac{U_{0}}{r}\right) \\
\quad-2 \overline{u_{r} u_{z}}-\frac{\partial U_{r}}{\partial Z} \cdots \cdots \cdots \cdots \cdots \cdots \cdots \cdots \cdots \cdots \cdots \cdots \cdots \cdots \cdots \cdots \cdots \cdots \cdots \cdots \cdots \cdots \cdots
\end{gathered}
$$

図 6 はその生成項等值線を描いた結果であるが第 1 曲がり管路の内壁, 第 2 曲がり管路の外壁には負の領 域が存在し図 5 の等值線分布とは大きく異なる.上式 の各項の值は第 1 曲がり管路で第 1 項は $10^{-3}$ 程度の 第 2 , 第 3 項はそれぞれ $10^{-5}, 10^{-4}$ 程度の值を雨側壁 

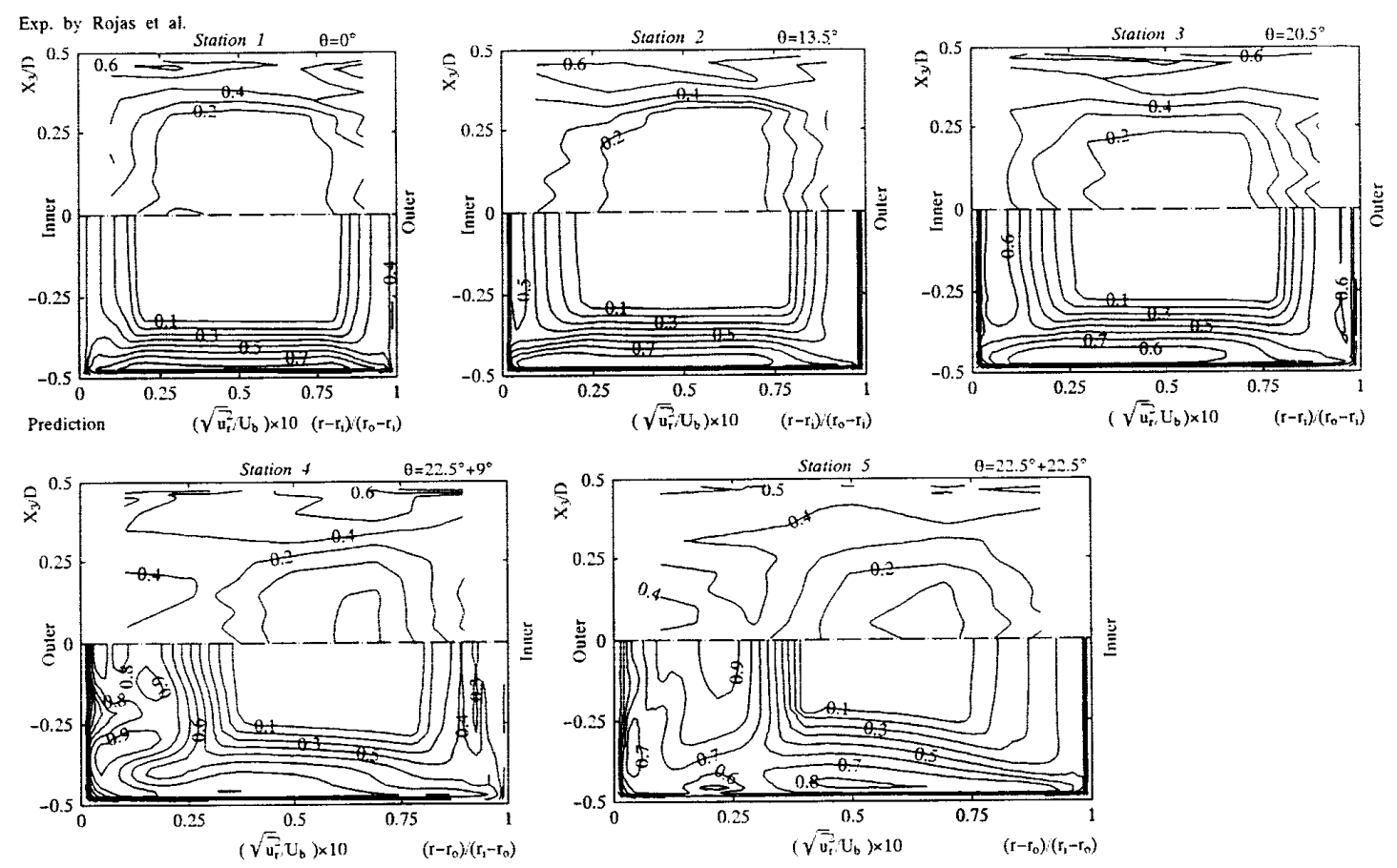

Fig. 5 Comparison of radial normal stress
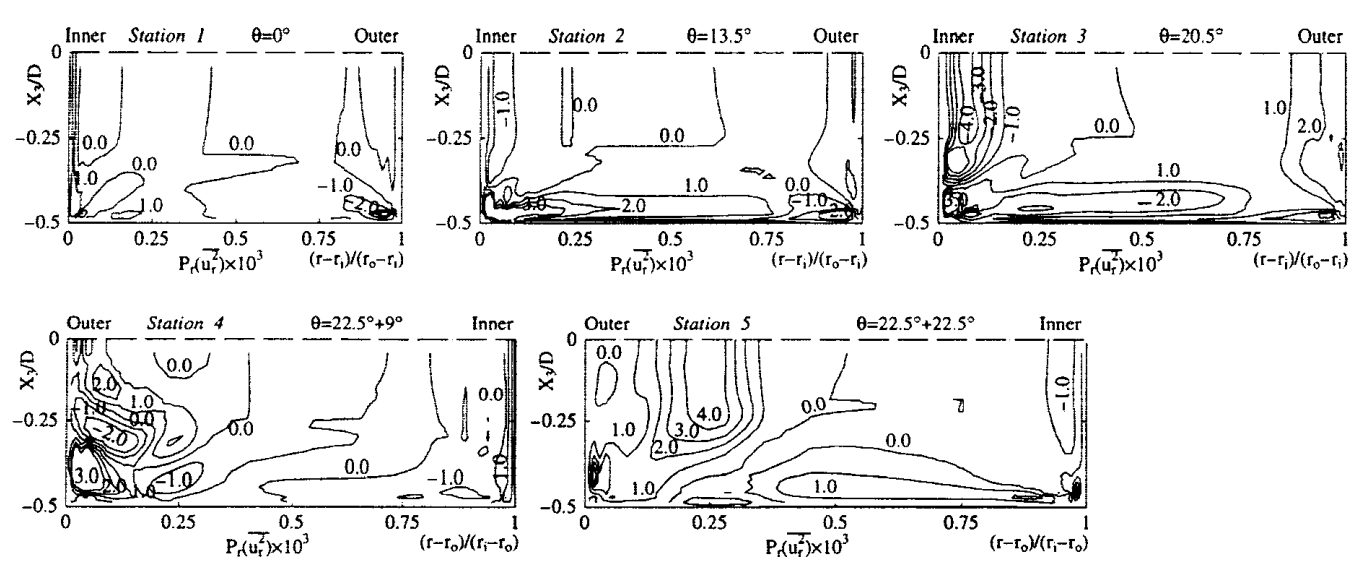

Fig. 6 Calculated production term of radial normal rtress

近傍で示し第 1 項が支配的である．第 2 曲がり管路に

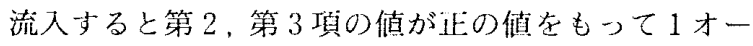
ダ程度增加することが外挂よりいくぶん離れた上下対 称軸近傍に認められる．第 1 項の速度こう配は第 1 曲 がり管队壁で正, 外壁で負, 第 2 曲がり管路では逆の 值を有するため第 1 曲がり管内壁，第 2 曲がり管外壁 には負の領域が形成されることになる。こうした頉の 領域が正に転ずるのは压力・ひずみ相関項を通して主

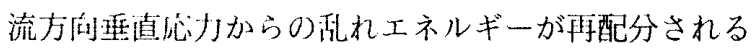
ことによるものと解积され、生力・ひずみ相関項が重 要な役割を担っていることを示唆している。また第 4 項は上下壁诵近傍に㳂って $10^{-3}$ 程度の值を有し上下 壁面の半烽方向画直志力の生成に奇与する。

汶 7 は内外壁に将行な力向の重直応力分有を比较し
た結果である、ト下壁面はこの俥直応力を扸制するた め, 半径方向垂直心力とは刘照的に内外壁近傍にて高 い值を示し上下垶近傍にて小さな值を取る。こうした 傾向は $\theta=0,13.5^{\circ}$ に扔ける計算結果より理解でき る. $\theta=20.5^{\circ}$ に至るとむしろ内壁側での増加が顕著 となり，第 2 の曲がり管路に流入すると第 10 曲がり 管路では内壁に相当し，第20曲がり管路では外壁に 相当する壁面近傍にて高い值の領域が大きく形成され る.こうした現象は他の垂直心力と共通した現象とし て指摘でき，各等值線も比較的類似の分帅を示してい る。訓算は队外壁の值を夹験値と比較し大きく見䅡も ってはいるが, 此較的良好に実験結果を再現している 娄のと思われる。

$4 \cdot 2$ せん断応力場における比較風 8 はせん断 

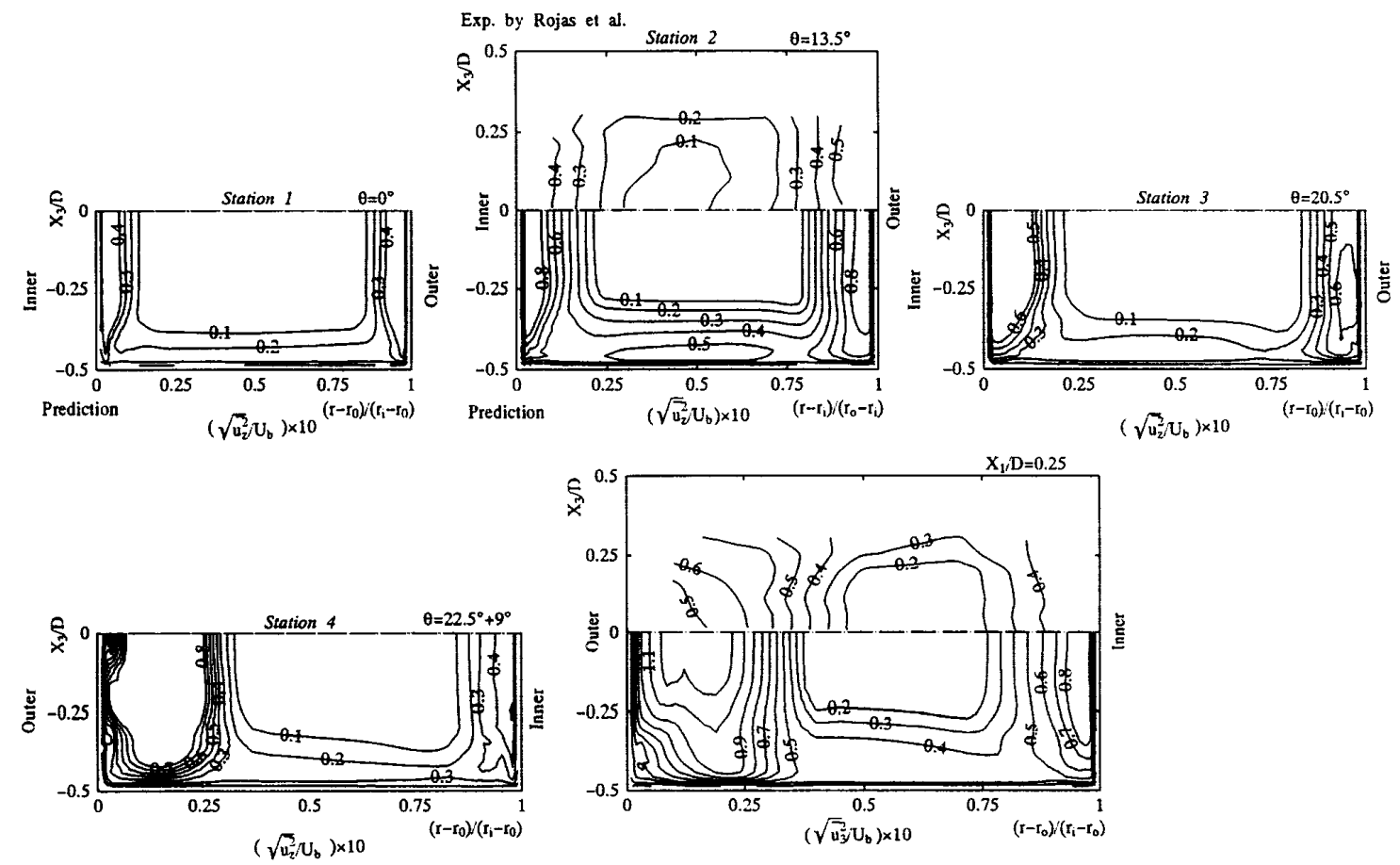

Fig. 7 Comparison of spanwise normal stress
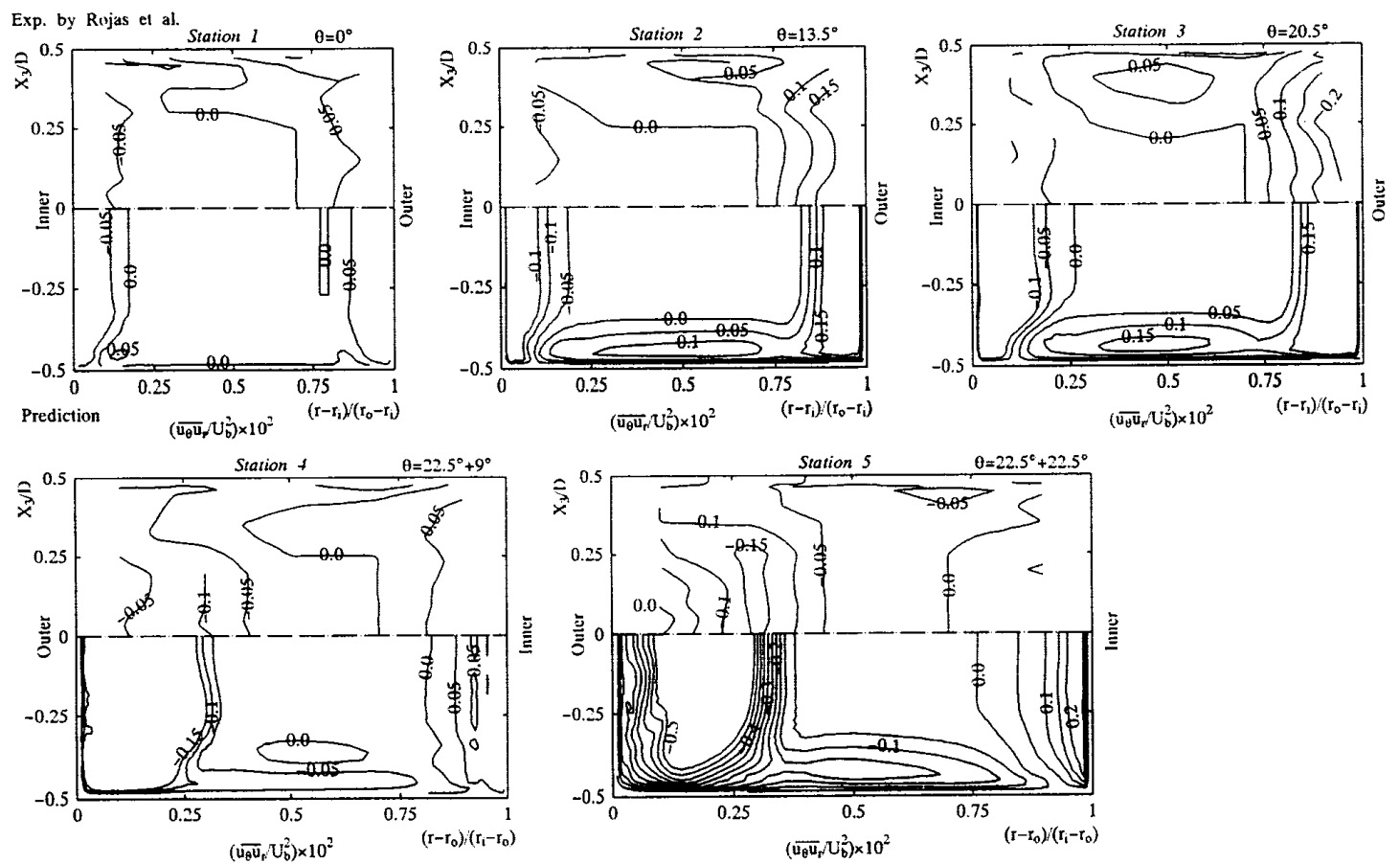

Fig. 8 Comparison of primary Reynolds shear stress

応力 $\overline{u_{\theta} u_{r}}$ の等值線を比較した結果である. $\theta=0^{\circ}$ の 実験結果よりせん断応力 $\overline{u_{\theta} u_{r}}$ は内外壁から管中心部 に向かって発達しその符号は内外壁とで異符号を取

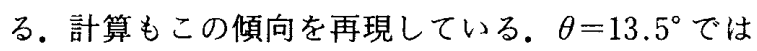
外壁側にて絶対值の高い值が生成されることが実験結 果より指摘できる.この点に関しては計算結果も同様 な結果を示しているが, 計算は内壁側, 底壁側でも絶
対值の大きな值を予測している. $\theta=20.5^{\circ}$ に至ると 計算は外壁近傍での等值線分布を比較的良好に予測し ているが, 内壁側でも比較的高い值を示し実験とは異 なる．第 2 の曲がり管路に流入すると $\theta=20.5^{\circ}+9^{\circ}$ の実験結果より内外壁に同程度の絶対值を有する領域 が認められるが, 計算は内壁により大きな值を予測し ている. $\theta=22.5^{\circ}+22.5^{\circ}$ に至ると両結果とも外壁側 

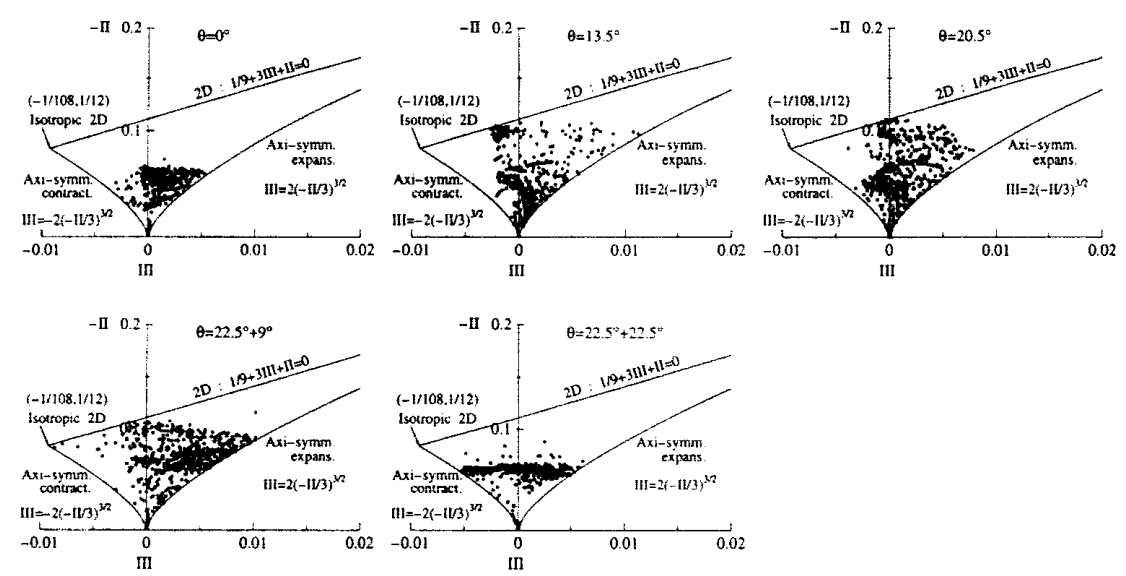

(a) S-shaped diffuser
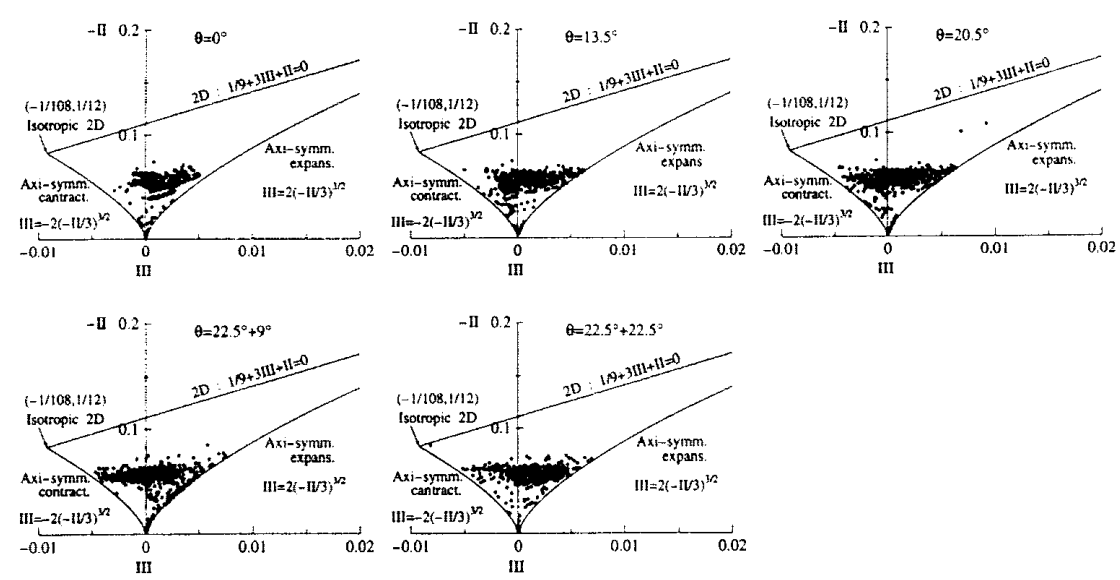

(b) S-shaped duct

Fig. 9 Calculated invariant maps

近傍に絶刘值の大きな領域を形成するが，計算はその 値を大きく予測する傾向にある。ん断応力 $\overline{u_{\theta} u_{r}}$ は 流れ場全体にわたり異符岇領域を形成するが，計算は その零ラインを比較的良好に予測している。

\section{$4 \cdot 3 \mathrm{~S}$ 字形状曲がり管路との比較 断面形状変} 化のない正方形断面の $\mathrm{S}$ 字形状管路と $\mathrm{S}$ 字形状ディ フューザ管路との乱流構造の相違を明らかにするため 不変量解析を行った。 S 字形状管路のデータは著者 ら(12)の計算結果を用いた。両者のレイノルズ数は曲 がり管路入口で同一である。非等方テンソルの第 2 ,

第 3 不変量は以下のように定義される。

$$
\begin{aligned}
& \mathrm{II}=-b_{i j} b_{i j} / 2 \\
& \mathrm{III}=b_{i j} b_{j k} b_{k i} / 3
\end{aligned}
$$

ここで $b_{i j}$ 証等方性を示すパラメータであり次のよ うに示さ机る。 $\delta_{i j}$ はクロネッカのデル夕記号を示す。

$$
b_{i j}=\left(\frac{\overline{u_{i} u_{j}}}{2 k}-\frac{\delta_{i j}}{3}\right) \text {. }
$$

図 9 は実験データが示された同じ位置に扔ける不変量 結果を比較したものである。S 字形状管路の不变量分
布としていずれの断面においても軸対称拡大状態 (Axi-symm. expans.) と軸対称収縮状態 (Axi-symm. contract）との間に第 2 不変量がほぼ一定状態で点在 していることが特徵的な分布として指摘できる。一 方, ディフューザ管路の不変量分布は特徴的な分布を 示す. $\theta=13.5,20.5^{\circ}$ の分布よりディフューザ部に 流入すると二次元乱流を示す $2 D$ 近傍に値が大きく散 在する.こうした $2 D$ ライン近傍に值が存在する現象 は自由水面を有する流れ場において認められ(18), 三方 向垂直応力のうち一成分方向の垂直応力が抑制される 乱流構造に変化したことを示唆している.さらに下流 の第 2 曲がり管路に流入すると軸対称搪大状態に沿つ て一次元乱流に向かって值が点在するが，これはディ フューザ部より主流方向垂㨁応力の生成が, 他の垂直 㐫力成分に比較して大きく促進される乱流構造に変化 したためと解釈される。

次にこうした垂值応力の強度変化を比較するため, 以下に定義する断面内の平均垂直応力強度を算出し両 結果を比較した。 


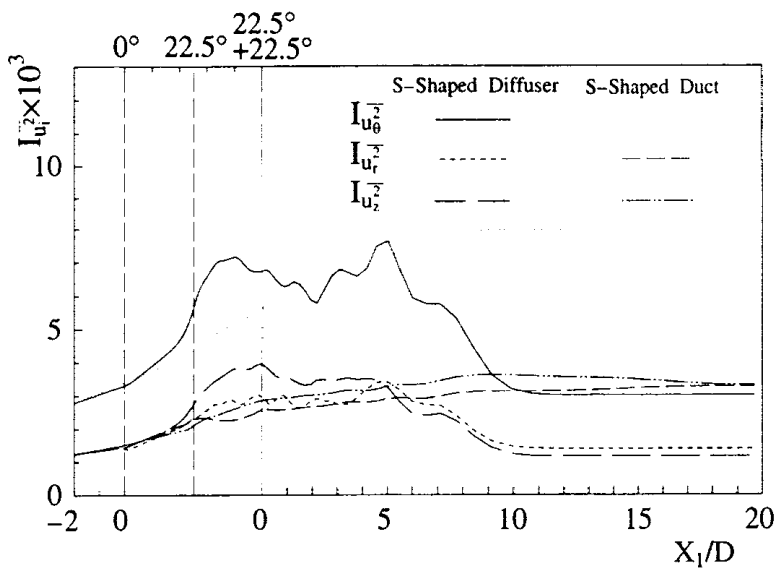

Fig. 10 Development of mean-normal stress level over cross section

$$
I_{u_{i}^{2}}=\frac{1}{U_{b}} \iint \frac{\sqrt{u_{i}^{2}}}{D D_{x 2}} d X_{2} d X_{3}
$$

式中 $I_{u}{ }^{2}, D_{x 2}$ はそれぞれ $i$ 軸方向の平均垂直応才, $X_{2}$ 軸方向の断面一辺長さを示している，結果を図 10 に示す、いずれの垂直応力ともディフューザ部におい てS字形状管路より大きな値を有しその発達程度は 第2曲がり管路のほうが顕著である。また主流方向車 直㤎の值は第 2 曲がり管路で他の二つの応力に対し て特に大きく、こうした結果が $\theta=22.5+9^{\circ}$ の軸対称 抁大状態に深って点在する不変留分布に現れているも のと解积念れる。 三方向重㨁充力成分のうちその生成 が最も㧕えられているのは半径方向の垂直心力である ことも図 10 よりわかる。

出儿直管部に流入すると雨者ではまったく異なる発 達を示す．S 字形状管路は出口直管部においても増加 し一定值に漸近するのに対し，゙ィフューザ管路は $X_{1} / D=6 〜 7$ 程度まで大きく変動した後減少し一定值 に落ちつく. $X_{1} / D=6 \sim 7$ 程度までの変動はディフュ ーザ部による影響であり，その後隇少するのはディフ ューザを設けたことによる速度減速に起因するものと 思わ扎る。また $X_{1} / D=12$ 程度の位㖵から非円形管 路に特徵的な第 2 種二次流れもコーナ部に形成され， 乱流構造として妥当なものであることを襄付けてい る.

\section{5. 結 論}

S字形状ディフューザの乱流場を対象に代数応力モ デル，境界適合座標系を用いて数値解析を行い応力場 に扔ける差異分析を行うと同時にS 字形状曲がり管 路との比較を行い以下の結論を得た。

（1）主流方向垂直応力は曲がりが進むにつれて第 1 曲がり管內壁, 第 2 曲がり管外壁にて大きな値を示
すが，本解析手法もこうした現象を再現した。また定 量的にも比較的良好に等值線分布を予測した。

（2）半径方向, 深さ方向の垂直応力等值線分布を 本解析手法は比較的良好に再現する。

（3）三成分の垂直応力は曲がりが進むにつれ第 1 曲がり管路内壁，第 2 曲がり管路の外壁にて高い值を 有し類似の等值線分布を示す。

（4）本解析手法はせん断応力 $\overline{u_{\theta} u_{r}}$ 分布をその零 ラインを含め比較的良好に再現している。

（5）不変量解析により S 字形状ディフューザ管 路内の乱流構造は二次元乱流に変化することを計算よ り示した.

（6）ディフューザ管路内の断面内平均垂直応力値 はS 字形状管路に比較していずれの応力も大きな值 を示すが, 出口直管路に流入すると大きく変動しなが ら減少し一定値に漸近していくことを予測した。

本研究を行うに際し，本学 4 年生の小出律文氏の協 力を得た。ここに記して謝意を表する。

\section{文献}

(1) Chang, S. M., Humphrey, J. A. C. and Modavi, A., Phys. Chem. Hydrodyn., 3(1983), 243-269.

(2) Choi, D., lacovides H. and Launder B.E., Trans. ASME, J. Fluids Eng., 111 (1989), 59-68.

(3) Bansod, P. and Bradshaw, P., Aeronaut. Q., 23(1972), $131-140$.

(4) Taylor, A. M. K. P., Whitelaw, J. H. and Yianneskis, M., NASA Contr. Rep., 3759 (1984).

(5) Taylor, A. M. K. P., Whitelaw, J. H. and Yianneskis, M., NASA Contr. Rep., 3550(1982).

(6) Shimizu, Y., Futaki, Y. and Maetin, C.S., Trans. ASME., J. Fluids Eng., 114(1992), 593 600.

（7）須藤活三・高睍敏弘・藤田昭文, 夕一术機械, 21 6(1993), 329-335.

(8) McMillan. O. J., NASA Contr., Rep., 3634 (1982).

(9) Rojas, J., Whitelaw, J. H. and Yianneskis, M., Imperial College of Sci. Technol., Dep. Mech. Eng.. FS/83/12 (1983).

(10) Rojas, J., Whitelaw, J.H. and Yianneksis, M., Three Dimensional Flow Phenomena in Fulid Machinery. (1985), FED-32, ASME.

（11）杉山均 - 秋山光庸 - 村.上泰隆, 機諭, 63 607, B (1997) $840-848$

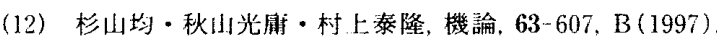
$832-839$.

(13) Lien, F. S. and Leschziner M. A., Engincering Tubulen ce Modelling and Experiments, 2(1993), $217228, \mathrm{El}$ sevier.

（14）杉山均 - 秋11光庿・村：上泰隆，機論，63 615， B(1997). 3505-3512.

(15) Rodi, W., Z. Angew. Math. Mech, 56 (1976), 219221

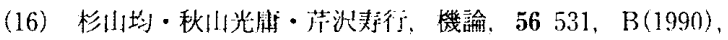
33283335.

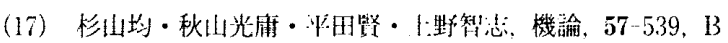
(1991), 22692276.

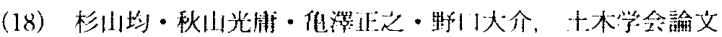
集, No. 565/II -39, (1997), 7383. 